\title{
Non-coding RNAs: a key to future personalized molecular therapy?
}

\author{
Marco Galasso', Maria Elena Sana' and Stefano Volinia*1,2,3
}

\begin{abstract}
Continual discoveries on non-coding RNA (ncRNA)

have changed the landscape of human genetics

and molecular biology. Over the past ten years it

has become clear that ncRNAs are involved in many

physiological cellular processes and contribute to

molecular alterations in pathological conditions. Several

classes of ncRNAs, such as small interfering RNAs,

microRNAs, PIWI-associated RNAs, small nucleolar RNAs

and transcribed ultra-conserved regions, are implicated

in cancer, heart diseases, immune disorders, and

neurodegenerative and metabolic diseases. ncRNAs

have a fundamental role in gene regulation and, given

their molecular nature, they are thus both emerging

therapeutic targets and innovative intervention tools.

Next-generation sequencing technologies (for example

SOLiD or Genome Analyzer) are having a substantial

role in the high-throughput detection of ncRNAs. Tools

for non-invasive diagnostics now include monitoring

body fluid concentrations of ncRNAs, and new clinical

opportunities include silencing and inhibition of ncRNAs

or their replacement and re-activation. Here we review

recent progress on our understanding of the biological

functions of human ncRNAs and their clinical potential.
\end{abstract}

\section{Introduction}

A non-coding RNA (ncRNA) is a functional RNA molecule that is not translated into a protein. Members of this class of molecule are involved in many cellular processes and include highly abundant and functionally important RNAs, such as transfer RNA (tRNA) and ribosomal RNA (rRNA), as well as small interfering RNAs (siRNAs), microRNAs (miRNAs), PIWI-associated RNAs (piRNAs), small nucleolar RNAs (snoRNAs), promoter-associated RNAs (PARs) and the recently identified telomere specific small

*Correspondence: stefano.volinia@unife.it

'Data Mining for Analysis of Microarrays, Department of Morphology and

Embryology, Università degli Studi di Ferrara, 44100 Ferrara, Italy

Full list of author information is available at the end of the article
RNAs (tel-sRNAs). Moreover, the recent demonstration that other ncRNAs, the ultraconserved genes or transcribed ultraconserved regions (T-UCRs) [1], are involved in human carcinogenesis suggests that the broad family of ncRNAs contributes to molecular alterations in several pathological conditions.

miRNAs are a conserved class of non-coding RNAs that regulate the translation of mRNAs (messenger RNAs) by inhibiting ribosome function, decapping the $5^{\prime}$ cap structure, deadenylating the poly(A) tail and degrading target mRNAs [2]. miRNAs are involved in mechanisms of gene regulation in both normal and diseased conditions and have a role during development, regulation of cell proliferation and apoptosis. The first miRNAs were identified in the nematode Caenorhabditis elegans as small RNAs that interacted with the 3' untranslated region (UTR) of the lin-14 mRNA to inhibit its expression [3]. miRNAs are single-stranded RNAs 19 to 24 nucleotides in length generated through a complex maturation process $[4,5]$ (Figure 1). miRNAs bind mostly to mRNA segments originating from the 3' UTRs of genes [6], but the mechanism of translational repression is only partially understood.

siRNAs are small RNAs, 21 to 22 nucleotides long, produced by Dicer cleavage of complementary dsRNA duplexes. siRNAs form complexes with Argonaute proteins and are involved in gene regulation, transposon control and defense against viruses.

piRNAs, 24 to 30 nucleotides in length, are produced by a Dicer-independent mechanism, associate with Piwiclass Argonaute proteins and are principally restricted to the germline and bordering somatic cells. piRNAs are important for transposon control $[7,8]$ and regulate chromatin state [9]. A recent study suggests that an antisense RNA may trigger transcriptional silencing of a partner sense tumor suppressor gene; this effect occurs both in cis and in trans and is Dicer-independent. The biochemical mediators of this silencing involve a Piwilike protein, and their role in mammals is just beginning to be understood $[5,10]$. In zebrafish, piRNAs have been implicated in germ cell maintenance and many of them were mapped to transposons, suggesting that they have a role in silencing repetitive elements in vertebrates [11]. 


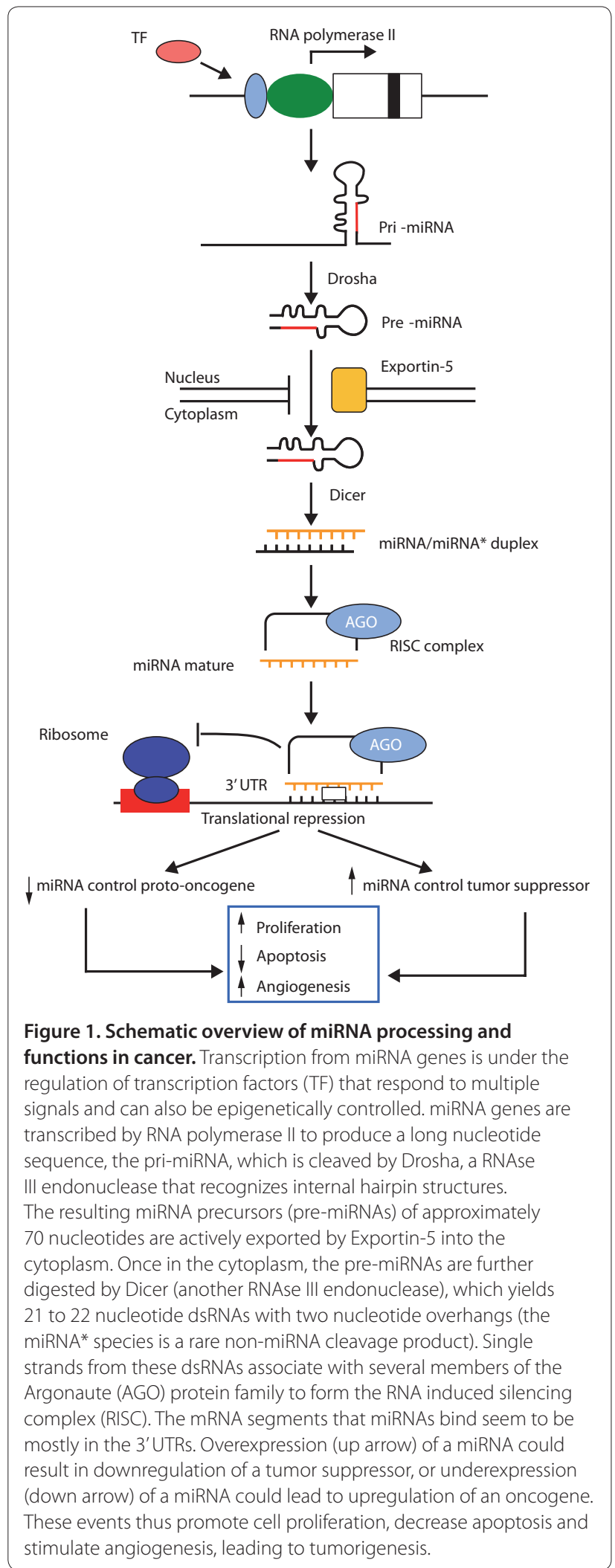

At the moment, no relationships between piRNAs and diseases have yet been discovered.
snoRNAs are small RNA molecules, approximately 60 to 300 nucleotides long, which generally serve as guides for the catalytic modification of selected ribosomal RNAs $[12,13]$. In vertebrates, most snoRNAs have been shown to reside in introns of protein-coding host genes and are processed out of the excised introns. Many snoRNAs have been described as retrogenes [14]. Some snoRNA is processed to a small RNA that can function like a miRNA [15].

PARs encompass a suite of long and short RNAs, including promoter-associated small RNAs (PASRs) and transcriptional initiation RNAs, that overlap promoter regions. Their function is so far unknown but they may possibly regulate transcription, as exogenous PASRs have been observed to reduce expression of genes with homologous promoter sequences [16].

tel-sRNAs in mouse embryonic stem cells are approximately 24 nucleotides long, Dicer-independent, and 2'-O-methylated at the 3' terminus. They are asymmetric, with specificity for G-rich telomere strands, are evolutionarily conserved from protozoa to mammals, and they may have a role in telomere maintenance [17].

Ultraconserved region (UCR) sequences are longer than 200 nucleotides in the genomes of human, mouse and rat. These are DNA sequences absolutely conserved, showing $100 \%$ homology among species with no insertions nor deletions [18]. UCRs can be located at fragile sites and genomic regions affected in various cancers called cancer-associated genomic regions. Genome-wide profiling has revealed that UCRs are differentially expressed in cancer and leukemia $[1,19]$.

Here, we discuss the basic mechanisms of action of human ncRNAs and review their clinical impact, including their emerging roles in the pathogenesis of cancer, leukemia and other diseases. We then focus on recent progress and future directions in drug development using the 'ncRNA strategy'. The identification of ncRNAs, in particular miRNAs and their respective targets, provides a host of potential biomarkers and novel therapeutic molecular tools.

\section{snoRNAs and disease}

Several studies have shown an association between snoRNAs and various diseases, including cancer. PraderWilli syndrome (PWS) is a congenital disease that is caused by the loss of paternal gene expression from a maternally imprinted region on chromosome 15 . The SNORD115 snoRNA (also called HBII-52) shows sequence complementarities to the alternatively spliced exon $\mathrm{Vb}$ of the serotonin receptor 5 -HT2C, located on chromosome X. HBII-52 regulates alternative splicing of 5 -HT2C by binding to a silencing element in exon Vb. PWS patients do not express HBII-52, so in this case the snoRNA seems to regulate the processing of an mRNA 
Table 1. Relevant miRNAs associated with leukemia

\begin{tabular}{|c|c|c|c|}
\hline Blood malignancy & miRNA & Regulation & References \\
\hline$\overline{C L L}$ & miR-15a miR-16-1, miR-181a, let-7a, miR-30d, miR-150, miR-92 & Downregulation & {$[28,29]$} \\
\hline $\begin{array}{l}\text { Pediatric Burkitt's lymphoma, Hodgkin's lymphoma, } \\
\text { diffuse large B cell lymphoma }\end{array}$ & miR-155, miR-17-92 & Upregulation & {$[28,29,72]$} \\
\hline Hodgkin's disease, Burkitt lymphoma cells & miR-9, let-7a & Upregulation & {$[73,74]$} \\
\hline B cell malignancies & miR-143, miR-145 & Downregulation & [75] \\
\hline AML & miR-127, miR-154, miR-299, miR-323, miR-368, miR-370 & Upregulation & {$[30,76]$} \\
\hline AML & miR-221, miR-222 & Downregulation & {$[31,32]$} \\
\hline Hematopoietic malignancies & miR-203 & Downregulation & [33] \\
\hline
\end{tabular}

located on a different chromosome [20]. Furthermore, another study related to PWS [21] demonstrated that deletion of Snord116 (also called Pwcr1 or MBII-85) causes growth deficiency and hyperphagia in mice, revealing a novel role for an ncRNA in growth and feeding regulation. snoRNAs have also been implicated in cancer development. The U50 snoRNA acts as a tumor suppressor in human prostate cancer [22] and in the development and/or progression of breast cancer [23].

\section{Ultraconserved regions}

There are 481 UCRs longer than 200 bases in the genomes of human, mouse and rat [18]. Many of these elements have been shown to have tissue-specific enhancer activity [24,25], and another subset of ultraconserved elements has been shown to be associated with control of splicing regulators by alternative splicing and nonsense-mediated decay [26]. The functional importance of UCRs has been emphasized by genomewide profiling, which revealed distinct UCR signatures in human leukemias and carcinomas. Calin et al. [1] have shown that some UCRs, whose expression may be regulated by miRNAs, are abnormally expressed in human chronic lymphocytic leukemia (CLL), and that the inhibition of an overexpressed UCR induces apoptosis in colon cancer cells. The correlation between the expression of UCRs and miRNAs in CLL patients raised the possibility of functional pathways in which two or more types of ncRNAs interact. This implication may support a model in which both coding and non-coding genes are involved and cooperate in human tumorigenesis.

\section{miRNAs and disease miRNAs in leukemia}

The role of miRNA in cancer was first discovered in leukemia. Calin et al. [27] reported evidence for the role of miRNAs in the pathogenesis of CLL: deletions and/or downregulation of miR-15a and miR-16-1 at 13q14 were associated with CLL. Cimmino et al. [28] demonstrated that this cluster can regulate the expression of the B-cell lymphoma 2 (BCL-2) oncogene. Other relevant alterations of miRNAs in CLL include downregulation of miR-181a, let-7a, miR-30d, miR-150 and miR-92 [29] and overexpression of miR-155. In Table 1 are shown the most important miRNAs associated with leukemia and hematological diseases. For example, miRNAs in the miR17-92 cluster are commonly amplified in B-cell lymphoma patients and, together with miR-155, they were among the earliest ncRNAs to be linked with cancer [28].

miRNA expression signatures have revealed differences between acute lymphoblastic leukemia (ALL) and acute myeloid leukemia (AML) [30]. Recently, specific miRNA signatures were correlated with karyotype alterations in AML: the main observation was that the $t(15 ; 17)$ translocation had a distinctive signature including the upregulation of a subset of miRNAs located in the human 14q32 imprinted domain. In another study, Garzon and colleagues [31] reported miRNA signatures associated with cytogenetics and prognosis of AML, with molecular abnormalities such as t(11q23), trisomy 8 and internal tandem duplications in the FLT3 receptor tyrosine kinase gene. Downregulation of miR-221 and miR-222 was observed in AML [32]. Bueno et al. [33] revealed a new dimension to the regulation of $\mathrm{v}$-Abl Abelson murine leukemia viral oncogene homolog $1(A B L 1)$ expression by demonstrating that $A B L 1$ is a direct target of miR-203. miR-203 is silenced by genetic and epigenetic mechanisms in hematopoietic malignancies expressing either $A B L 1$ or $B C R-A B L 1$. Restoration of miR-203 expression reduces $A B L 1$ and $B C R-A B L 1$ levels and inhibits cell proliferation. Venturini and co-workers [34] have shown the expression of the miR-17-92 polycistron in $\mathrm{CD}_{4} 4^{+}$ cells in chronic myelogenous leukemia and the regulation of this cluster by BCR-ABL1 and c-MYC.

\section{miRNAs in solid cancers}

Immediately after the first reports on the involvement of miRNAs in leukemia and lymphoma, a flurry of reports unveiled a role for miRNAs in solid cancers. The availability of high-throughput techniques for miRNA profiling allowed a detailed investigation of many cancer types. These studies immediately showed that miRNAs are 
Table 2. Overview of prominent miRNAs associated with solid cancers

\begin{tabular}{|c|c|c|c|}
\hline Type of solid cancer & miRNA & Function & References \\
\hline Breast cancer & miR-21, miR-125b & oncomiR & [37] \\
\hline Breast cancer metastasis & miR-335, miR-206, miR-126 & Metastasis suppressor & {$[77,78]$} \\
\hline Lung adenocarcinoma & let-7a, miR-143, miR-145 & Tumor suppressor & {$[32,39]$} \\
\hline Lung adenocarcinoma & miR-17-92 cluster, miR-106b/93/25 cluster & oncomiR & {$[32,40]$} \\
\hline Pancreatic ductal carcinoma & miR-196a, miR-196b & oncomiR & {$[41,42]$} \\
\hline Ovarian carcinoma & miR-199a/b, miR-140, miR-145, miR-204, miR-125a/b & Tumor suppressor & [79] \\
\hline Ovarian carcinoma & miR-141, miR-200a/b/c & oncomiR & [79] \\
\hline Hepatocellular carcinoma & miR-21, miR-224, miR-34a, miR-221/222, miR-106a, miR-203 & oncomiR & {$[43,44]$} \\
\hline Hepatocellular carcinoma & miR-122a, miR-422b, miR-145, miR-199a & Tumor suppressor & {$[43,44]$} \\
\hline Thyroid papillary cancer & miR-146b, miR-221, miR-222, miR-181b, miR-155, miR-224 & oncomiR & {$[45,78,80]$} \\
\hline
\end{tabular}

differentially expressed in normal and tumor samples and can be used to classify tumors of different origins [35,36]. Table 2 shows a summary of known miRNAs correlated with solid cancers.

Some miRNAs that had been earlier characterized in leukemia were found to be commonly overexpressed in solid cancers: miR-17-5p, miR-20a, miR-21, miR-92, miR-106a, miR-107, miR-146, miR-155, miR-181 and miR-221/222 [36]. Other miRNAs were characterized in relation to specific tumor types. For example, miR-21 was highly expressed in breast tumors [37] and a risk variant of a miR-125b binding site in the bone morphogenetic protein receptor type IB gene $(B M P R 1 B)$ was also associated with breast cancer pathogenesis [38,39]. The overexpressed miR-106b/93/25 cluster modulated an antiapoptotic response after TGF- $\beta$ stimulation mediated by BCL2-like 11 (BIM) [40]. Various studies on pancreatic cancer highlighted significant differences between tumors and chronic pancreatitis, normal pancreas and pancreatic cell lines. Pancreatic tumors have a characteristic miRNA profile; a pancreatic ductal adenocarcinoma-related miRNA signature was defined [41]. In a study on 65 resected pancreatic ductal adenocarcinomas with matched benign adjacent pancreas by Bloomston et al. [42], miR-196a was associated with poor survival. Several studies have shown that specific miRNAs are aberrantly expressed in malignant hepatocellular carcinoma compared with normal hepatocytes $[43,44]$. The altered expression of some miRNAs has been associated with particular risk factors, such as hepatitis B virus infection or alcohol use [44]. Many of these miRNAs are upregulated in hepatocellular carcinoma as compared with normal thyroid cells and hyperplastic nodules [45].

\section{miRNAs as oncogenes and tumor suppressors}

By targeting and controlling the expression of mRNA, miRNAs can control highly complex signal-transduction pathways and other biological pathways. The biological roles of miRNAs in cancer suggest a correlation with prognosis and therapeutic outcome. A study [46] demonstrated that more than $50 \%$ of miRNA genes are located in cancer-associated genomic regions or in fragile sites, suggesting that miRNAs may be more important in the pathogenesis of human cancers than previously thought. miRNAs are also involved in advanced stages of tumor progression, which underlines their roles as metastasis activators or suppressors.

There is emerging evidence that some miRNAs can function as either oncogenes or tumor suppressors. Those miRNAs whose expression is increased in tumors may be considered as oncogenes - also called 'oncomiRs' which promote tumor development by inhibiting tumor suppressor genes and/or genes controlling cell differentiation or apoptosis.

The miR-17-92 cluster is an miRNA polycistron located at chromosome 13q31, a genomic locus that is amplified in lung cancer and in several kinds of lymphoma, including diffuse large B-cell lymphoma. This cluster has been found to be regulated by $\mathrm{c}-\mathrm{MYC}$, an important transcription factor that is overexpressed in many human cancers [47].

Microarray analysis revealed that miR-221, miR-21 and $\mathrm{miR}-181 \mathrm{a} / \mathrm{b} / \mathrm{c}$ are strongly upregulated in glioblastoma samples compared with normal brain controls [48]. The data suggested that these miRNAs may act as antiapoptotic factors in human malignant disease. In several types of lymphomas, including Burkitt's lymphoma, the expression of miR-155 is increased [49]. Furthermore, miR-155 is located in the only phylogenetically conserved region of the $\mathrm{B}$-cell receptor inducible $(B I C)$ gene, suggesting that miR-155 may be responsible for $B I C$ 's oncogenic activity [50].

Conversely, underexpressed miRNAs in cancers, such as some members of the let-7 family, may function as tumor suppressor genes by regulating oncogenes and/or 
genes that control cell differentiation or apoptosis. Several studies indicate that the $R A S$ oncogene is a direct target of let-7, which negatively regulates $R A S$ by pairing to its 3' UTR for translational repression, and some recent studies have focused on let-7 miRNA binding site polymorphisms in the KRAS 3' UTR that have been associated with reduced survival in oral cancers [51]. Other miRNAs that have a potential role as tumor suppressors include miR-15 and miR-16, which induce apoptosis by targeting the mRNAs for the anti-apoptotic gene B-cell lymphoma $2(B C L-2)$ [28], myeloid cell leukemia sequence 1 (MCL1), cyclin D1 (CCND1) and wingless-type MMTV integration site family member 3A (WNT3A) [52]. Downregulation of these miRNAs has been reported in CLL, pituitary adenomas and prostate carcinoma. Restoration of miR-29b in AML cells induces apoptosis and dramatically reduces tumorigenicity in a xenograft leukemia model: this study also indicated that miR-29b targets apoptosis, cell cycle and proliferation pathways [31].

miR-221 and miR-222 are two highly similar miRNAs whose upregulation has been recently described in several types of human tumors and for which an oncogenic role was explained by the discovery of their target p27, a key cell cycle regulator. The ectopic overexpression of miR-221 is able, on its own, to confer a high growth advantage to tumors derived from the LNCaP cell line in severe combined immunodeficient mice [53]. In line with these results, treatment of established subcutaneous tumors derived from the highly aggressive PC3 cell line with the anti-miR-221/222 antagomiR (an anti-miRNA conjugated to cholesterol) reduced tumor growth by increasing expression of the cyclin-dependent kinase inhibitor p27 [53]. These findings suggest that modulating levels of let-7, miR-15, miR-16, miR-221/222 or miR-29b might be of therapeutic potential in various different types of cancers.

\section{miRNAs in tumor invasion and metastasis}

The first description of a miRNA in relation to tumor invasion and metastasis was by $\mathrm{Ma}$ et al. [54], who identified miR-10b upregulation in metastatic breast cancer cells with respect to the primary tumors. miR-10b was expressed in breast cancer in the following way: downregulated in cancer when compared with normal breast [32] but overexpressed in metastatic cancer when compared with non-metastatic tumors [54]. Subsequently, Huang and colleagues [55] identified two miRNAs, miR-373 and miR-520c, that promote cancer cell migration and invasion in vitro and in vivo by blocking the adhesion molecule CD44. A significant upregulation of miR-373 and negative correlation with CD44 expression was found in breast cancer patients with metastasis.
Recently, much interest has been focused on the role of miRNAs in the maintenance of the so-called 'cancer stem cells'. Human breast tumors contain a breast cancer stem cell (BCSC) population with properties reminiscent of normal stem cells. Three miRNA clusters, miR-200c/141, miR-200b/200a/429 and miR-183/96/182, are downregulated in human BCSCs, normal human and murine mammary stem/progenitor cells and embryonic carcinoma cells. miR-200c modulates expression of $B$ lymphoma Mo-MLV insertion region 1 homolog (BMI1), an essential protein for the self-renewal of adult stem cells. miR-200c suppresses normal mammary outgrowth in vivo and tumorigenicity of human BCSCs. The coordinated downregulation of these miRNA clusters, and the analogous regulation of clonal expansion by miR200c, provides a molecular link that connects BCSCs to normal stem cells [56].

\section{From in vitro findings to clinical biomarkers and therapies}

Because of their links to pathological conditions and, in particular, cancer development and progression, miRNAs and other ncRNAs might become useful biomarkers for diagnostic purposes. ncRNA expression levels can be determined by in situ hybridization, for example on a tumor section and its normal adjacent counterparts. Mature-miRNA-specific stem loop RT$\mathrm{PCR}$ is an alternative detection system for very short ncRNAs. Recently, deep-sequencing technologies, such as SOLiD (Applied Biosystems, Foster City, USA) or Genome Analyzer (Illumina, San Diego, USA), have become available for high-throughput detection of ncRNAs.

The key question is how to translate the molecular signatures determined in the laboratory to the clinical setting. As described above, several studies have identified associations of miRNA with disease prognosis, survival and mortality in biopsies (in pancreatic cancer [42] and colon cancer [57]). A possible innovative approach for early detection is represented by the determination of circulating miRNAs in plasma [58] or urine. In an application of this approach, Tanaka et al. [58] have shown that miR-92a levels are decreased in the plasma of leukemia patients and suggested the ratio in plasma of miR-92a to miR-638 (the latter is stably expressed in human plasma) as a tool for the clinical detection of leukemia. Differential expression of miRNAs in plasma of patients with colorectal cancer has also been proposed as a basis for screening [59].

Non-oncological disciplines could also benefit from measuring circulating ncRNAs. For example, the plasma concentration of miR-208 might be a useful indicator of myocardial injury [60]. Plasma miRNAs and other circulating or secreted ncRNAs therefore represent 
Table 3. Methodological characteristics of chemical and biological therapeutic tools*

\begin{tabular}{|c|c|c|c|c|c|}
\hline $\begin{array}{l}\text { Therapeutic } \\
\text { modulation }\end{array}$ & Chemical-biological characteristics & Strategies & Delivery system & Clinical application & References \\
\hline 2'-Ome AMOs & $\begin{array}{l}\text { Modified 2-OH residues of the ribose } \\
\text { 2'-O-methyl }\end{array}$ & $\begin{array}{l}\text { Inhibition of mature } \\
\text { miRNA }\end{array}$ & $\begin{array}{l}\text { RNA-liposome complex; } \\
\text { conjugation of a cholesterol }\end{array}$ & Silence oncomiR & [81-83] \\
\hline 2'-MOE AMOs & $\begin{array}{l}\text { Modified 2-OH residues of the ribose } \\
\text { 2'-O-methoxyethyl }\end{array}$ & $\begin{array}{l}\text { Inhibition of mature } \\
\text { miRNA }\end{array}$ & $\begin{array}{l}\text { Oligonucleotide-liposome } \\
\text { complex; conjugation of a } \\
\text { cholesterol }\end{array}$ & Silence oncomiR & [81-83] \\
\hline $\begin{array}{l}\text { AMOs (RNase } \\
\text { H-based) }\end{array}$ & $\begin{array}{l}\text { Contains a short stretch of centrally } \\
\text { located } 2^{\prime} \text { deoxy residues }\end{array}$ & Inhibition of pri-miRNA & $\begin{array}{l}\text { Oligonucleotide-liposome } \\
\text { complex; conjugation of a } \\
\text { cholesterol }\end{array}$ & $\begin{array}{l}\text { Silence polycistronic } \\
\text { miRNA cluster }\end{array}$ & {$[61,84]$} \\
\hline LNA-antagomiR & $\begin{array}{l}\text { Contains one or more nucleotide } \\
\text { building blocks in which an extra } \\
\text { methylene bridge fixes the ribose } \\
\text { moiety either in C3'-endo or C2'-endo } \\
\text { conformation' }\end{array}$ & $\begin{array}{l}\text { Inhibition of mature } \\
\text { miRNA }\end{array}$ & Unconjugated & Silence oncomiR & [63] \\
\hline $\begin{array}{l}\text { pre-miRNA-like } \\
\text { shRNAs }\end{array}$ & $\begin{array}{l}\text { Natural pre-miRNA, for a more persistent } \\
\text { miRNA replacement }\end{array}$ & $\begin{array}{l}\text { Replacement of mature } \\
\text { miRNA }\end{array}$ & $\begin{array}{l}\text { Plasmid or viral vector with } \\
\text { either polymerase II or III } \\
\text { promoter upstream of a } \\
\text { shRNA }\end{array}$ & $\begin{array}{l}\text { Restore tumor } \\
\text { suppressor miRNA }\end{array}$ & {$[85,86]$} \\
\hline $\begin{array}{l}\text { Double-stranded } \\
\text { miRNA mimetics }\end{array}$ & $\begin{array}{l}\text { Equivalent to endogenous Dicer } \\
\text { product; analogous structure to an siRNA }\end{array}$ & $\begin{array}{l}\text { Replacement of mature } \\
\text { miRNA }\end{array}$ & $\begin{array}{l}\text { Oligonucleotide-liposome } \\
\text { complex; conjugation of } \\
\text { a cholesterol; linking with } \\
\text { delivery proteins; other } \\
\text { nanotechnology-based } \\
\text { conjugation; transgene } \\
\text { approach }\end{array}$ & $\begin{array}{l}\text { Restore tumor } \\
\text { suppressor miRNA }\end{array}$ & [87] \\
\hline $\begin{array}{l}\text { Synthetic } \\
\text { miRNAs }\end{array}$ & Designed related target mRNA & Selected silence target & $\begin{array}{l}\text { Conjugation of a protein } \\
\text { interaction target }\end{array}$ & Tumor suppressor role & {$[64,65]$} \\
\hline 'miRNA sponges' & $\begin{array}{l}\text { Multiple miRNA binding sites into the } \\
\text { 3'UTR of a reporter gene encoding } \text { destabilized GFP driven by the CMV } \\
\text { promoter }\end{array}$ & $\begin{array}{l}\text { Inhibition of mature } \\
\text { miRNA cluster }\end{array}$ & Sponge plasmid vector & Silence oncomiR family & [66] \\
\hline
\end{tabular}

*Abbreviations: GFP, green fluorescent protein; CMV, cytomegalovirus.

${ }^{1}$ C3'-endo (beta-D-LNA) or C2'-endo (alpha-L-LNA) stereoisomer.

potential novel biomarkers for early detection of various pathological conditions.

\section{Therapeutic silencing and inhibition of ncRNAs}

The fundamental roles of miRNAs in development, differentiation and malignancy suggest that this class of molecules are potential targets for novel therapeutics. Antisense oligonucleotide approaches, used for inhibition, and siRNA-like technologies, used for replacement, are currently being explored for therapeutic modulation of miRNAs.

There are currently several approaches to silencing ncRNAs (Table 3). Most of these methods have been applied to miRNAs, the class of ncRNAs that currently holds the highest potential for clinical applications. Specific knockdown of miRNAs by anti-miRNA oligonucleotides (AMOs), double-strand miRNA mimetics and overexpression of miRNA duplexes have been conducted in vitro and in vivo (Table 4). AntagomiRs have been found capable of inhibiting specific miRNAs in mouse models. RNase H-based AMOs, which work primarily in the nucleus, may be useful for targeting polycistronic pri-miRNAs, such as the miR-17-92 cluster [61]. Elmen et al. [62] showed that systemic administration of 16-nucleotide unconjugated locked nucleic acid (LNA)-AMO complementary to the 5' end of miR-122 leads to specific, dose-dependent silencing of miR-122 with no hepatotoxicity in mice. Another study from the same group demonstrated that the simple systemic delivery of an unconjugated LNA-AMO effectively antagonizes the liver-expressed miR-122 in non-human primates. Acute administration by intravenous injections of 3 or $10 \mathrm{mg} / \mathrm{kg}$ LNA-AMO to African green monkeys resulted in uptake of the LNA-AMO in the cytoplasm of primate hepatocytes and formation of stable heteroduplexes between the LNA-AMO and miR-122 [63]. This route seems attractive for in vivo applications that are inaccessible to RNA interference technology, such as inhibition of oncogenic miRNAs.

Strategies based on synthetic miRNAs may also open interesting avenues. Recently, Tsuda et al. [64,65] 
Table 4. Overview of in vivo delivery systems for snoRNAs and miRNAs*

\begin{tabular}{|c|c|c|c|c|c|}
\hline miRNA & Disease state & Biological target & In vivo model & Delivery system & References \\
\hline miR-100 & Nasopharyngeal cancer & $P \mid k 1$ & $\begin{array}{l}\text { 6- to 8-week-old SCID BALB/C } \\
\text { female mice }\end{array}$ & $\begin{array}{l}\text { siRNA and ionizing radiation and } \\
\text { potential miRNAs that might } \\
\text { regulate Plk1 expression }\end{array}$ & [88] \\
\hline Synthetic miR-16 & Metastatic prostate cancer & $C D K 1$ and $C D K 2$ & Bone metastasis mode mice & Injected into tail veins & [89] \\
\hline miR-155 & Myeloproliferative disorder & SHIP1 & $\begin{array}{l}\text { Mice, specific knockdown of } \\
\text { SHIP1 in the hematopoietic } \\
\text { system }\end{array}$ & $\begin{array}{l}\text { Retroviral delivery of a miR-155- } \\
\text { formatted siRNA against SHIP1 }\end{array}$ & [90] \\
\hline $\begin{array}{l}\text { SNORD116 } \\
\text { (PWCR1/HBII-85) }\end{array}$ & Prader-Willi syndrome & $\begin{array}{l}\text { Bioinformatic screen } \\
\text { located } 23 \text { possible } \\
\text { targets }\end{array}$ & C57BL/6 mice & Snord116del mice & [21] \\
\hline miR-147 & Inflammation & $\begin{array}{l}\text { Cytokine expression in } \\
\text { macrophages stimulated } \\
\text { with ligands to Toll-like } \\
\text { receptors: TLR2, TLR3, } \\
\text { TLR4 }\end{array}$ & LPS-stimulated mouse & $\begin{array}{l}\text { Peritoneal macrophages were } \\
\text { transfected with } 40 \mathrm{nM} \text { control } \\
\text { miRNA mimics or mouse miR-147 } \\
\text { mimics }\end{array}$ & [91] \\
\hline LNA-antimiR-122 & Hypercholesterolemia & miR-122 liver specific & $\begin{array}{l}\text { Normal and } \\
\text { hypercholesterolemic } \\
\text { mice; normal African green } \\
\text { monkeys }\end{array}$ & $\begin{array}{l}\text { Intravenous injections } \\
\text { unconjugated }\end{array}$ & [62] \\
\hline LNA-antimiR-21 & Glioma & miR-21 & Athymic nude mice & Intracranial cell implantation & [92] \\
\hline miR-34a & Normal & E2F family & Nude mice & $\begin{array}{l}\text { Subcutaneous administration of } \\
\text { miR-34a/collagen complexes }\end{array}$ & [93] \\
\hline mir-17-92 cluster & Normal & $c-M y c$ & $\begin{array}{l}\text { Mice reconstituted with } \\
\text { hematopoietic stem cells } \\
\text { expressing mir-17-19b }\end{array}$ & $\begin{array}{l}\text { Perfusion cells treated by } \\
\text { retroviral vector }\end{array}$ & [94] \\
\hline
\end{tabular}

*Abbreviations: CDK, cyclin-dependent kinase; E2F, E2 transcription factor; LPS, lipopolysaccharide; PIk1, Polo-like kinase 1; SCID, severe combined immunodeficient; SHIP1, Src homology-2 domain-containing inositol 5-phosphatase 1; TLR, Toll-like receptor.

designed and developed synthetic miRNAs corresponding to duplex miRNAs by introducing 3-nucleotide loops in GU-rich regions of the 3' UTR sequence of the gliomaassociated antigen-1 (Gli-1) gene. They found that one of these (Gli-1-miRNA-3548) and its corresponding duplex (Duplex-3548) inhibited proliferation of Gli-1+ ovarian and pancreatic tumor cells.

An alternative to chemically modified anti-ncRNA oligonucleotides is offered by de novo engineered ncRNA inhibitors that can be exogenously expressed in cells. These 'miRNA sponges' are competitive inhibitors to transcripts expressed from strong promoters, containing multiple, tandem binding sites of an miRNA of interest. Sponges inhibit miRNAs with a complementary heptameric seed, such that a single sponge can be used to block an entire miRNA family with the same seed. Fluorescent reporter genes can be used to identify and sort the treated cells [66]. Another route to therapeutic targeting of ncRNAs, in particular miRNAs, could be represented by inhibition of Drosha, Dicer or other components in the maturation pathway. This method, stepping into a pleiotropic physiological pathway, may, however, be difficult to make specific in its therapeutic effect.

\section{Therapeutic replacement or re-activation of ncRNAs}

When ncRNA activity is lost in affected cells, an alternative therapeutic strategy is needed. Here the approach is represented by the 'replacement' of defective or absent RNA effectors. An example of such an approach is the use, as described earlier for the miR-29b tumor suppressor, of synthetic oligonucleotides, in this particular case aimed at improving treatment response in AML [31]. Gene therapy approaches for therapeutic miRNA replacement hold considerable potential. Modified adenovirus or adeno-associated virus vectors have been effective for gene delivery into tissues. Nevertheless, a study [67] has also shown that such an approach can cause fatality in mice, possibly resulting from oversaturation of the cellular miRNA/short hairpin RNA pathway (shRNA; a short sequence of RNA that makes a tight hairpin turn and can be used to silence gene expression). Lentiviral delivery of short hairpin RNAs is another system for the delivery of shRNA constructs (controlled by either RNA polymerase II or III promoters) designed to mimic the pri-miRNA by including the miRNA flanking sequence into the shRNA stem $[68,69]$. The multi-inlet focusing technique used for the Bcl-2 antisense deoxyoligonucleotide [70] can be extended to 
condense miRNA and overcome the challenge of limited transfection efficiency faced by delivery of 'naked' miRNAs. Moreover, epigenetic modifications of miRNAs, such as methylation, suggest the use of epigenetic therapy with drugs that modulate DNA methylation or histone deacetylation. Activation of tumor suppressor miRNAs, such as miR-127, by chromatin-modifying drugs may inhibit tumor growth through downregulation of their target oncogenes [71].

\section{Conclusions and perspectives}

ncRNAs represent a novel kind of human posttranscriptional regulatory tool. They can specifically target different genes, often in a one-to-many manner. Fine-tuning the level of a single ncRNA might therefore affect many pathways in a pleiotropic manner. Several studies have contributed to our understanding of the functions of ncRNAs and of their impact on the pathogenesis of complex diseases. Abnormal miRNA expression is now regarded as an intrinsic feature of cancer growth and progression. These observations highlight the clinical potential of ncRNAs as biomarkers for diagnosis, prognosis and prediction of therapeutic outcome. Because of the significant impact of miRNAs, it would be useful to develop a personalized expression dataset such as a 'molecular diagnostic database'. The new deep sequencing technologies might here provide the ability to translate laboratory potential into clinical practice. Inhibition and re-activation of ncRNAs will then be the final steps in this discovery chain, leading to a therapeutic approach. Engineered synthetic miRNAs could be custom-applied to specifically regulate gene expression based on the patient's genomic profile.

\section{Abbreviations}

$A B L 1, v$-abl Abelson murine leukemia viral oncogene homolog 1; $A M L$, acute myeloid leukemia; AMO, anti-miRNA oligonucleotide; BCL-2, B-cell lymphoma 2; BCSC, breast cancer stem cell; BIC, B-cell receptor inducible; CLL, chronic lymphocytic lymphoma; dsRNA, double stranded RNA; LNA, locked nucleic acid; miRNA, microRNA; ncRNA, non-coding RNA; PAR, promoter-associated RNA; PASR, promoter-associated small RNA; piRNA, PIWI-associated RNA; pre-miRNA, precursor miRNA; pri-miRNA, primary miRNA; RISC, RNA induced silencing complex; shRNA, small hairpin RNA; siRNA, small interfering RNA; snoRNA, small nucleolar RNA; tel-sRNA, telomere-specific small RNA; UCR, ultraconserved region; UTR, untranslated region.

\section{Author details}

'Data Mining for Analysis of Microarrays, Department of Morphology and Embryology, Università degli Studi di Ferrara, 44100 Ferrara, Italy ${ }^{2}$ Comprehensive Cancer Center, Ohio State University, Columbus, OH 43210, USA ${ }^{3}$ Biomedical Informatics, Ohio State University, Columbus, OH 43210, USA

\section{Competing interests}

The authors declare that they have no competing interests.

\section{Authors' contributions}

MG, MES and SV mined the literature and discussed and wrote the manuscript.

\section{Acknowledgements}

SV is supported by AIRC (IG 8588), PRIN MIUR 2008 and Regione Emilia

Romagna PRRIITT BioPharmaNet grants.
Published: 18 February 2010

\section{References}

1. Calin GA, Liu CG, Ferracin M, Hyslop T, Spizzo R, Sevignani C, Fabbri M, Cimmino A, Lee EJ, Wojcik SE, Shimizu M, Tili E, Rossi S, Taccioli C, Pichiorri F, Liu X, Zupo S, Herlea V, Gramantieri L, Lanza G, Alder H, Rassenti L, Volinia S, Schmittgen TD, Kipps TJ, Negrini M, Croce CM: Ultraconserved regions encoding ncRNAs are altered in human leukemias and carcinomas. Cancer Cell 2007, 12:215-229.

2. FilipowiczW, Bhattacharyya SN, Sonenberg N: Mechanisms of posttranscriptional regulation by microRNAs: are the answers in sight? Nat Rev Genet 2008, 9:102-114.

3. Lee RC, Feinbaum RL, Ambros V: The C. elegans heterochronic gene lin-4 encodes small RNAs with antisense complementarity to lin-14. Cell 1993, 75:843-854

4. Rana TM: Illuminating the silence: understanding the structure and function of small RNAs. Nat Rev Mol Cell Biol 2007, 8:23-36.

5. Peters L, Meister G: Argonaute proteins: mediators of RNA silencing. Mol Cell 2007, 26:611-623.

6. Doench JG, Sharp PA: Specificity of microRNA target selection in translational repression. Genes Dev 2004, 18:504-511.

7. Brennecke J, Aravin AA, Stark A, Dus M, Kellis M, Sachidanandam R, Hannon GJ: Discrete small RNA-generating loci as master regulators of transposon activity in Drosophila. Cell 2007, 128:1089-1103.

8. Grimson A, Srivastava M, Fahey B, Woodcroft BJ, Chiang HR, King N, Degnan BM, Rokhsar DS, Bartel DP: Early origins and evolution of microRNAs and Piwi-interacting RNAs in animals. Nature 2008, 455:1193-1197.

9. Malone CD, Hannon GJ: Small RNAs as guardians of the genome. Cell 2009, 136:656-668.

10. Yu W, Gius D, Onyango P, Muldoon-Jacobs K, Karp J, Feinberg AP, Cui H: Epigenetic silencing of tumour suppressor gene $\mathrm{p} 15$ by its antisense RNA. Nature 2008, 451:202-206.

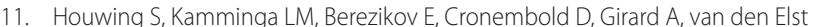
H, Filippov DV, Blaser H, Raz E, Moens CB, Plasterk RH, Hannon GJ, Draper BW, Ketting RF: A role for Piwi and piRNAs in germ cell maintenance and transposon silencing in zebrafish. Cell 2007, 129:69-82.

12. Kiss T: Small nucleolar RNAs: an abundant group of noncoding RNAs with diverse cellular functions. Cell 2002, 109:145-148.

13. Bachellerie JP, Cavaille J, Huttenhofer A: The expanding snoRNA world. Biochimie 2002, 84:775-790.

14. Luo Y, Li S: Genome-wide analyses of retrogenes derived from the human box H/ACA snoRNAs. Nucleic Acids Res 2007, 35:559-571.

15. Ender C, Krek A, Friedlander MR, Beitzinger M, Weinmann L, Chen W, Pfeffer S, Rajewsky N, Meister G: A human snoRNA with microRNA-like functions. Mol Cell 2008, 32:519-528.

16. Taft RJ, Kaplan CD, Simons C, Mattick JS: Evolution, biogenesis and function of promoter-associated RNAs. Cell Cycle 2009, 8:2332-2338.

17. Cao F, Li X, Hiew S, Brady H, Liu Y, Dou Y: Dicer independent small RNAs associate with telomeric heterochromatin. RNA 2009, 15:1274-1281.

18. Bejerano G, Pheasant M, Makunin I, Stephen S, Kent WJ, Mattick JS, Haussler D: Ultraconserved elements in the human genome. Science 2004, 304:1321-1325.

19. Rossi S, Sevignani C, Nnadi SC, Siracusa LD, Calin GA: Cancer-associated genomic regions (CAGRs) and noncoding RNAs: bioinformatics and therapeutic implications. Mamm Genome 2008, 19:526-540.

20. Kishore S, Stamm S: The snoRNA HBII-52 regulates alternative splicing of the serotonin receptor 2C. Science 2006, 311:230-232.

21. Ding F, Li HH, Zhang S, Solomon NM, Camper SA, Cohen P, Francke U: SnoRNA Snord 116 (Pwcr1/MBII-85) deletion causes growth deficiency and hyperphagia in mice. PLOS ONE 2008, 3:e1709.

22. Dong XY, Rodriguez C, Guo P, Sun X, Talbot JT, Zhou W, Petros J, Li Q, Vessella RL, Kibel AS, Stevens VL, Calle EE, Dong JT: SnoRNA U50 is a candidate tumor-suppressor gene at $6 q 14.3$ with a mutation associated with clinically significant prostate cancer. Hum Mol Genet 2008, 17:1031-1042.

23. Dong XY, Guo P, Boyd J, Sun X, Li Q, Zhou W, Dong JT: Implication of snoRNA U50 in human breast cancer. J Genet Genomics 2009, 36:447-454.

24. Pennacchio LA, Ahituv N, Moses AM, Prabhakar S, Nobrega MA, Shoukry M, Minovitsky S, Dubchak I, Holt A, Lewis KD, Plajzer-Frick I, Akiyama J, De Val S, Afzal V, Black BL, Couronne O, Eisen MB, Visel A, Rubin EM: In vivo enhancer analysis of human conserved non-coding sequences. Nature 2006, 444:499-502. 
25. Bejerano G, Lowe CB, Ahituv N, King B, Siepel A, Salama SR, Rubin EM, Kent WJ, Haussler D: A distal enhancer and an ultraconserved exon are derived from a novel retroposon. Nature 2006, 441:87-90.

26. Ni JZ, Grate L, Donohue JP, Preston C, Nobida N, O'Brien G, Shiue L, Clark TA, Blume JE, Ares M Jr: Ultraconserved elements are associated with homeostatic control of splicing regulators by alternative splicing and nonsense-mediated decay. Genes Dev 2007, 21:708-718.

27. Calin GA, Dumitru CD, Shimizu M, Bichi R, Zupo S, Noch E, Aldler H, Rattan S, Keating M, Rai K, Rassenti L, Kipps T, Negrini M, Bullrich F, Croce CM: Frequent deletions and down-regulation of micro-RNA genes miR15 and miR16 at $13 q 14$ in chronic lymphocytic leukemia. Proc Natl Acad Sci USA 2002, 99:15524-15529.

28. Cimmino A, Calin GA, Fabbri M, lorio MV, Ferracin M, Shimizu M, Wojcik SE, Aqeilan RI, Zupo S, Dono M, Rassenti L, Alder H, Volinia S, Liu CG, Kipps TJ, Negrini M, Croce CM: miR-15 and miR-16 induce apoptosis by targeting BCL2. Proc Natl Acad Sci USA 2005, 102:13944-13949.

29. Fulci V, Chiaretti S, Goldoni M, Azzalin G, Carucci N, Tavolaro S, Castellano L, Magrelli A, Citarella F, Messina M, Maggio R, Peragine N, Santangelo S, Mauro FR, Landgraf P, TuschI T, Weir DB, Chien M, Russo JJ, Ju J, Sheridan R, Sander C, Zavolan M, Guarini A, Foa R, Macino G: Quantitative technologies establish a novel microRNA profile of chronic lymphocytic leukemia. Blood 2007, 109:4944-4951.

30. Mi S, Lu J, Sun M, Li Z, Zhang H, Neilly MB, Wang Y, Qian Z, Jin J, Zhang Y, Bohlander SK, Le Beau MM, Larson RA, Golub TR, Rowley JD, Chen J: MicroRNA expression signatures accurately discriminate acute lymphoblastic leukemia from acute myeloid leukemia. Proc Natl Acad Sci USA 2007, 104:19971-19976.

31. Garzon R, Liu S, Fabbri M, Liu Z, Heaphy CE, Callegari E, Schwind S, Pang J, Yu J, Muthusamy N, Havelange V, Volinia S, Blum W, Rush LJ, Perrotti D, Andreeff M, Bloomfield CD, Byrd JC, Chan K, Wu LC, Croce CM, Marcucci G: MicroRNA$29 \mathrm{~b}$ induces global DNA hypomethylation and tumor suppressor gene reexpression in acute myeloid leukemia by targeting directly DNMT3A and 3B and indirectly DNMT1. Blood 2009, 113:6411-6418.

32. Spizzo R, Nicoloso MS, Croce CM, Calin GA: SnapShot: microRNAs in cancer Cell 2009, 137:586-586.e1.

33. Bueno MJ, Perez de Castro I, Gomez de Cedron M, Santos J, Calin GA, Cigudosa JC, Croce CM, Fernandez-Piqueras J, Malumbres M: Genetic and epigenetic silencing of microRNA-203 enhances ABL1 and BCR-ABL1 oncogene expression. Cancer Cell 2008, 13:496-506

34. Venturini L, Battmer K, Castoldi M, Schultheis B, Hochhaus A, Muckenthaler MU, Ganser A, Eder M, Scherr M: Expression of the miR-17-92 polycistron in chronic myeloid leukemia (CML) CD34+ cells. Blood 2007, 109:4399-4405.

35. Lu J, Getz G, Miska EA, Alvarez-Saavedra E, Lamb J, Peck D, Sweet-Cordero A, Ebert BL, Mak RH, Ferrando AA, Downing JR, Jacks T, Horvitz HR, Golub TR: MicroRNA expression profiles classify human cancers. Nature 2005 435:834-838.

36. Volinia S, Calin GA, Liu CG, Ambs S, Cimmino A, Petrocca F, Visone R, lorio M, Roldo C, Ferracin M, Prueitt RL, Yanaihara N, Lanza G, Scarpa A, Vecchione A, Negrini M, Harris CC, Croce CM: A microRNA expression signature of human solid tumors defines cancer gene targets. Proc Natl Acad Sci USA 2006, 103:2257-2261.

37. Zhu S, Wu H, Wu F, Nie D, Sheng S, Mo YY: MicroRNA-21 targets tumor suppressor genes in invasion and metastasis. Cell Res 2008, 18:350-359.

38. Saetrom P, Biesinger J, Li SM, Smith D, Thomas LF, Majzoub K, Rivas GE, Alluin J, Rossi JJ, Krontiris TG, Weitzel J, Daly MB, Benson AB, Kirkwood JM, O'Dwyer PJ, Sutphen R, Stewart JA, Johnson D, Larson GP: A risk variant in an miR$125 \mathrm{~b}$ binding site in BMPR1B is associated with breast cancer pathogenesis. Cancer Res 2009, 69:7459-7465.

39. Bandres E, Cubedo E, Agirre X, Malumbres R, Zarate R, Ramirez N, Abajo A, Navarro A, Moreno I, Monzo M, Garcia-Foncillas J: Identification by real-time PCR of 13 mature microRNAs differentially expressed in colorectal cancer and non-tumoral tissues. Mol Cancer 2006, 5:29.

40. Petrocca F, Visone R, Onelli MR, Shah MH, Nicoloso MS, de Martino I, \|liopoulos D, Pilozzi E, Liu CG, Negrini M, Cavazzini L, Volinia S, Alder H, Ruco LP, Baldassarre G, Croce CM, Vecchione A: E2F1-regulated microRNAs impair TGFbeta-dependent cell-cycle arrest and apoptosis in gastric cancer. Cancer Cell 2008, 13:272-286.

41. Szafranska AE, Davison TS, John J, Cannon T, Sipos B, Maghnouj A, Labourier E, Hahn SA: MicroRNA expression alterations are linked to tumorigenesis and non-neoplastic processes in pancreatic ductal adenocarcinoma. Oncogene 2007, 26:4442-4452.
42. Bloomston M, Frankel WL, Petrocca F, Volinia S, Alder H, Hagan JP, Liu CG, Bhatt D, Taccioli C, Croce CM: MicroRNA expression patterns to differentiate pancreatic adenocarcinoma from normal pancreas and chronic pancreatitis. JAMA 2007, 297:1901-1908.

43. Pineau P, Volinia S, McJunkin K, Marchio A, Battiston C, Terris B, Mazzaferro V, Lowe SW, Croce CM, Dejean A: miR-221 overexpression contributes to liver tumorigenesis. Proc Natl Acad Sci USA 2009, 107:264-269.

44. Murakami Y, Yasuda T, Saigo K, Urashima T, Toyoda H, Okanoue T, Shimotohno $\mathrm{K}$ : Comprehensive analysis of microRNA expression patterns in hepatocellular carcinoma and non-tumorous tissues. Oncogene 2006, 25:2537-2545.

45. Nikiforova MN, Chiosea SI, Nikiforov YE: MicroRNA expression profiles in thyroid tumors. Endocr Pathol 2009, 20:85-91

46. Calin GA, Sevignani C, Dumitru CD, Hyslop T, Noch E, Yendamuri S, Shimizu M, Rattan S, Bullrich F, Negrini M, Croce CM: Human microRNA genes are frequently located at fragile sites and genomic regions involved in cancers. Proc Natl Acad Sci USA 2004, 101:2999-3004

47. Inomata M, Tagawa H, Guo YM, Kameoka Y, Takahashi N, Sawada K: MicroRNA-17-92 down-regulates expression of distinct targets in different B-cell lymphoma subtypes. Blood 2009, 113:396-402.

48. Ciafre SA, Galardi S, Mangiola A, Ferracin M, Liu CG, Sabatino G, Negrini M, Maira G, Croce CM, Farace MG: Extensive modulation of a set of microRNAs in primary glioblastoma. Biochem Biophys Res Commun 2005, 334:1351-1358.

49. Eis PS, Tam W, Sun L, Chadburn A, Li Z, Gomez MF, Lund E, Dahlberg JE: Accumulation of miR-155 and BIC RNA in human B cell lymphomas. Proc Natl Acad Sci USA 2005, 102:3627-3632.

50. Tili E, Croce CM, Michaille JJ: miR-155: on the crosstalk between inflammation and cancer. Int Rev Immuno/ 2009, 28:264-284.

51. Christensen BC, Moyer BJ, Avissar M, Ouellet LG, Plaza SL, McClean MD, Marsit CJ, Kelsey KT: A let-7 microRNA-binding site polymorphism in the KRAS $3^{\prime}$ UTR is associated with reduced survival in oral cancers. Carcinogenesis 2009, 30:1003-1007.

52. Bonci D, Coppola V, Musumeci M, Addario A, Giuffrida R, Memeo L, D’Urso L, Pagliuca A, Biffoni M, Labbaye C, Bartucci M, Muto G, Peschle C, De Maria R: The miR-15a-miR-16-1 cluster controls prostate cancer by targeting multiple oncogenic activities. Nat Med 2008, 14:1271-1277.

53. Mercatelli N, Coppola V, Bonci D, Miele F, Costantini A, Guadagnoli M, Bonanno E, Muto G, Frajese GV, De Maria R, Spagnoli LG, Farace MG, Ciafre SA: The inhibition of the highly expressed miR-221 and miR-222 impairs the growth of prostate carcinoma xenografts in mice. PLOS ONE 2008, 3:e4029.

54. Ma L, Teruya-Feldstein J, Weinberg RA. Tumour invasion and metastasis initiated by microRNA-10b in breast cancer. Nature 2007, 449:682-688.

55. Huang Q, Gumireddy K, Schrier M, le Sage C, Nagel R, Nair S, Egan DA, Li A, Huang G, Klein-Szanto AJ, Gimotty PA, Katsaros D, Coukos G, Zhang L, Pure E, Agami R: The microRNAs miR-373 and miR-520c promote tumour invasion and metastasis. Nat Cell Bio/ 2008, 10:202-210.

56. Shimono Y, Zabala M, Cho RW, Lobo N, Dalerba P, Qian D, Diehn M, Liu H, Panula SP, Chiao E, Dirbas FM, Somlo G, Pera RA, Lao K, Clarke MF: Downregulation of miRNA-200c links breast cancer stem cells with normal stem cells. Cell 2009, 138:592-603.

57. Schetter AJ, Nguyen GH, Bowman ED, Mathe EA, Yuen ST, Hawkes JE, Croce CM, Leung SY, Harris CC: Association of inflammation-related and microRNA gene expression with cancer-specific mortality of colon adenocarcinoma. Clin Cancer Res 2009, 15:5878-5887.

58. Tanaka M, Oikawa K, Takanashi M, Kudo M, Ohyashiki J, Ohyashiki K, Kuroda M: Down-regulation of miR-92 in human plasma is a novel marker for acute leukemia patients. PLOS ONE 2009, 4:e5532.

59. Ng EK, Chong WW, Jin H, Lam EK, Shin VY, Yu J, Poon TC, Ng SS, Sung JJ: Differential expression of microRNAs in plasma of patients with colorectal cancer: a potential marker for colorectal cancer screening. Gut 2009, 58:1375-1381

60. Ji X, Takahashi R, Hiura Y, Hirokawa G, Fukushima Y, Iwai N: Plasma miR-208 as a biomarker of myocardial injury. Clin Chem 2009, 55:1944-1949.

61. Wu H, Lima WF, Zhang H, Fan A, Sun H, Crooke ST: Determination of the role of the human RNase $\mathrm{H} 1$ in the pharmacology of DNA-like antisense drugs. J Biol Chem 2004, 279:17181-17189.

62. Elmen J, Lindow M, Silahtaroglu A, Bak M, Christensen M, Lind-Thomsen A, Hedtjarn M, Hansen JB, Hansen HF, Straarup EM, McCullagh K, Kearney P, Kauppinen S: Antagonism of microRNA-122 in mice by systemically administered LNA-antimiR leads to up-regulation of a large set of 
predicted target mRNAs in the liver. Nucleic Acids Res 2008, 36:1153-1162.

63. Elmen J, Lindow M, Schutz S, Lawrence M, Petri A, Obad S, Lindholm M, Hedtjarn M, Hansen HF, Berger U, Gullans S, Kearney P, Sarnow P, Straarup EM, Kauppinen S: LNA-mediated microRNA silencing in non-human primates. Nature 2008, 452:896-899.

64. Tsuda N, Ishiyama S, Li Y, loannides CG, Abbruzzese JL, Chang DZ: Synthetic microRNA designed to target glioma-associated antigen 1 transcription factor inhibits division and induces late apoptosis in pancreatic tumor cells. Clin Cancer Res 2006, 12:6557-6564.

65. Tsuda N, Mine T, loannides CG, Chang DZ: Synthetic microRNA targeting glioma-associated antigen-1 protein. Methods Mol Biol 2009, 487:435-449.

66. Ebert MS, Neilson JR, Sharp PA: MicroRNA sponges: competitive inhibitors of small RNAs in mammalian cells. Nat Methods 2007, 4:721-726.

67. Grimm D, Streetz KL, Jopling CL, Storm TA, Pandey K, Davis CR, Marion P, Salazar F, Kay MA: Fatality in mice due to oversaturation of cellular microRNA/short hairpin RNA pathways. Nature 2006, 441:537-541.

68. Zeng $Y$, Yi R, Cullen BR: Recognition and cleavage of primary microRNA precursors by the nuclear processing enzyme Drosha. EMBO J 2005, 24:138-148

69. Chang K, Elledge SJ, Hannon GJ: Lessons from Nature: microRNA-based shRNA libraries. Nat Methods 2006, 3:707-714.

70. Koh CG, Zhang X, Liu S, Golan S, Yu B, Yang X, Guan J, Jin Y, Talmon Y, Muthusamy N, Chan KK, Byrd JC, Lee RJ, Marcucci G, Lee L: Delivery of antisense oligodeoxyribonucleotide lipopolyplex nanoparticles assembled by microfluidic hydrodynamic focusing. J Control Release 2009, 141:62-69.

71. Grunweller A, Hartmann RK: Locked nucleic acid oligonucleotides: the next generation of antisense agents? BioDrugs 2007, 21:235-243.

72. Costinean S, Zanesi N, Pekarsky Y, Tili E, Volinia S, Heerema N, Croce CM: Pre-B cell proliferation and lymphoblastic leukemia/high-grade lymphoma in E(mu)-miR155 transgenic mice. Proc Natl Acad Sci USA 2006, 103:7024-7029.

73. Nie K, Gomez M, Landgraf P, Garcia JF, Liu Y, Tan LH, Chadburn A, Tuschl T, Knowles DM, Tam W: MicroRNA-mediated down-regulation of PRDM1/ Blimp-1 in Hodgkin/Reed-Sternberg cells: a potential pathogenetic lesion in Hodgkin lymphomas. Am J Pathol 2008, 173:242-252.

74. Sampson VB, Rong NH, Han J, Yang Q, Aris V, Soteropoulos P, Petrelli NJ, Dunn SP, Krueger LJ: MicroRNA let-7a down-regulates MYC and reverts MYCinduced growth in Burkitt lymphoma cells. Cancer Res 2007, 67:9762-9770.

75. Akao Y, Nakagawa Y, Kitade Y, Kinoshita T, Naoe T: Downregulation of microRNAs-143 and -145 in B-cell malignancies. Cancer Sci 2007. 98:1914-1920.

76. Dixon-Mclver A, East P, Mein CA, Cazier JB, Molloy G, Chaplin T, Andrew Lister $T$, Young BD, Debernardi S: Distinctive patterns of microRNA expression associated with karyotype in acute myeloid leukaemia. PLOS ONE 2008, 3:e2141.

77. Negrini M, Calin GA: Breast cancer metastasis: a microRNA story. Breast Cancer Res 2008, 10:203.

78. He H, Jazdzewski K, Li W, Liyanarachchi S, Nagy R, Volinia S, Calin GA, Liu CG, Franssila K, Suster S, Kloos RT, Croce CM, de la Chapelle A: The role of microRNA genes in papillary thyroid carcinoma. Proc Natl Acad Sci USA 2005, 102:19075-19080.

79. Iorio MV, Visone R, Di Leva G, Donati V, Petrocca F, Casalini P, Taccioli C, Volinia S, Liu CG, Alder H, Calin GA, Menard S, Croce CM: MicroRNA signatures in human ovarian cancer. Cancer Res 2007, 67:8699-8707.

80. Chen YT, Kitabayashi N, Zhou XK, Fahey TJ 3rd, Scognamiglio T: MicroRNA analysis as a potential diagnostic tool for papillary thyroid carcinoma. Mod Pathol 2008, 21:1139-1146.
81. Krutzfeldt J, Rajewsky N, Braich R, Rajeev KG, Tuschl T, Manoharan M, Stoffel M: Silencing of microRNAs in vivo with 'antagomirs'. Nature 2005, 438:685-689

82. Bijsterbosch MK, Rump ET, De Vrueh RL, Dorland R, van Veghel R, Tivel KL, Biessen EA, van Berkel TJ, Manoharan M: Modulation of plasma protein binding and in vivo liver cell uptake of phosphorothioate oligodeoxynucleotides by cholesterol conjugation. Nucleic Acids Res 2000, 28:2717-2725.

83. Bijsterbosch MK, Manoharan M, Dorland R, Van Veghel R, Biessen EA, Van Berkel TJ: bis-Cholesteryl-conjugated phosphorothioate oligodeoxynucleotides are highly selectively taken up by the liver. J Pharmacol Exp Ther 2002, 302:619-626.

84. Cerritelli SM, Frolova EG, Feng C, Grinberg A, Love PE, Crouch RJ: Failure to produce mitochondrial DNA results in embryonic lethality in Rnaseh1 null mice. Mol Cell 2003, 11:807-815.

85. Brummelkamp TR, Bernards R, Agami R: A system for stable expression of short interfering RNAs in mammalian cells. Science 2002, 296:550-553.

86. Miyagishi M, Taira K: U6 promoter-driven siRNAs with four uridine $3^{\prime}$ overhangs efficiently suppress targeted gene expression in mammalian cells. Nat Biotechnol 2002, 20:497-500.

87. Soutschek J, Akinc A, Bramlage B, Charisse K, Constien R, Donoghue M, Elbashir S, Geick A, Hadwiger P, Harborth J, John M, Kesavan V, Lavine G, Pandey RK, Racie T, Rajeev KG, Rohl I, Toudjarska I, Wang G, Wuschko S, Bumcrot D, Koteliansky V, Limmer S, Manoharan M, Vornlocher HP: Therapeutic silencing of an endogenous gene by systemic administration of modified siRNAs. Nature 2004, 432:173-178.

88. Shi W, Alajez NM, Bastianutto C, Hui AB, Mocanu JD, Ito E, Busson P, Lo KW, $\mathrm{Ng} \mathrm{R}$, Waldron J, O'Sullivan B, Liu FF: Significance of Plk1 regulation by miR-100 in human nasopharyngeal cancer. Int J Cancer 2009, in press.

89. Takeshita F, Patrawala L, Osaki M, Takahashi RU, Yamamoto Y, Kosaka N, Kawamata M, Kelnar K, Bader AG, Brown D, Ochiya T: Systemic delivery of synthetic microRNA-16 inhibits the growth of metastatic prostate tumors via downregulation of multiple cell-cycle genes. Mol Ther 2009, 18:181-187.

90. O'Connell RM, Chaudhuri AA, Rao DS, Baltimore D: Inositol phosphatase SHIP1 is a primary target of miR-155. Proc Natl Acad Sci USA 2009, 106:7113-7118.

91. Liu G, Friggeri A, Yang Y, Park YJ, Tsuruta Y, Abraham E: miR-147, a microRNA that is induced upon Toll-like receptor stimulation, regulates murine macrophage inflammatory responses. Proc Natl Acad Sci USA 2009, 106:15819-15824.

92. Corsten MF, Miranda R, Kasmieh R, Krichevsky AM, Weissleder R, Shah K. MicroRNA-21 knockdown disrupts glioma growth in vivo and displays synergistic cytotoxicity with neural precursor cell delivered S-TRAIL in human gliomas. Cancer Res 2007, 67:8994-9000.

93. Tazawa $\mathrm{H}$, Tsuchiya N, Izumiya M, Nakagama H: Tumor-suppressive miR-34a induces senescence-like growth arrest through modulation of the E2F pathway in human colon cancer cells. Proc Natl Acad Sci USA 2007, 104:15472-15477.

94. He L, Thomson JM, Hemann MT, Hernando-Monge E, Mu D, Goodson S, Powers S, Cordon-Cardo C, Lowe SW, Hannon GJ, Hammond SM: A microRNA polycistron as a potential human oncogene. Nature 2005, 435:828-833.

doi:10.1186/gm133

Cite this article as: Galasso M, et al: Non-coding RNAs: a key to future personalized molecular therapy? Genome Medicine 2010, 2:12. 